\title{
PENGARUH PERBEDAAN DOSIS LARUTAN PUPUK NPK MAJEMUK TERHADAP KEBERHASILAN PERTUMBUHAN BAWANG MERAH (Allium ascalonicum L.)
}

\author{
(The Effect of Differences Dosage of NPK Compound Successful Growth of Shallots \\ (Allium ascalonicum L.))
}

\author{
K. Amalia Damayanti ${ }^{1}$, Prasodjo Soedomo ${ }^{2}$ \\ ${ }^{1}$ Program Studi Agroteknologi, Fakultas Pertanian, Universitas Singaperbangsa Karawang \\ Jl. HS. Ronggo Waluyo, Telukjambe Timur, Kawarang, Jawa Barat, Indonesia 41361 \\ ${ }^{2}$ Balai Penelitian Tanaman Sayuran Lembang (BALITSA) Jl. Tangkuban Perahu 571, \\ Lembang, Bandung, Jawa Barat, Indonesia 40391 \\ Penulis Korespoden: khusnaamaliadamayanti@gmail.com
}

Article Submitted: 25-02-2021

Article Accepted: 21-05-2021

\begin{abstract}
This research aims to determine the type of shallot variety and the correct dosage for maximum growth and yield of shallot plants. The research method used an experimental method with the experimental design used was a single factor randomized block design (RBD) consisting of 6 treatments, namely A (Sembrani Variety and 100). ml/polybag), B (Sembrani variety and $120 \mathrm{ml} /$ polybag), C (Sembrani variety and $140 \mathrm{ml} /$ polybag), D (Mentes variety and 100 $\mathrm{ml} /$ polybag), E (Mentes variety and $120 \mathrm{ml} /$ polybag), and $\mathrm{F}$ (Mentes variety and $140 \mathrm{ml} /$ polybag) was repeated 4 times so that there were a total of 24 experimental units. The effect of the treatment was analyzed using variance and if the $\mathrm{F}$ test at the 5\% level was significant, then to find out the best treatment was continued with the DMRT (Duncan Multiple Range Test) further test at the 5\% level. The results showed that there was a significant effect on the types of shallot varieties with different dosages of NPK compound, on all research parameters. Treatment $\mathrm{E}$ gave the highest yield at plant height $(44.49 \mathrm{~cm})$, the weight of fresh tubers with leaves/clump $(7.11$ $\mathrm{g}$ ), the weight of fresh tubers with leaves/plot $(19.93 \mathrm{~g})$, the weight of dry tubers with leaves/clump $(5.90 \mathrm{~g})$, weight dry tubers with leaves/plot $(16.35 \mathrm{~g})$. While treatment $\mathrm{D}$ gave the highest yield on the number of tillers (3.14), the number of leaves (6.97), the number of tubers (3.14). Treatment $\mathrm{C}$ gave the highest yield on tuber diameter $(22.58 \mathrm{~mm})$ and treatment $\mathrm{A}$ tuber length $(31.48 \mathrm{~mm})$.
\end{abstract}

Keywords: Sembrani, Mentes, Shallot, Growth, NPK

\section{PENDAHULUAN}

Bawang merah (Allium ascalonicum L.) merupakan komoditi hortikultura yang tergolong sayuran rempah. Sayuran rempah ini banyak dibutuhkan terutama sebagai pelengkap bumbu masakan guna menambah cita rasa dan kenikmatan masakan. Selain sebagai bumbu masak, bawang merah dapat bermanfaat untuk obat kesehatan (Estu et al., 2007). Saat ini ekstrak dari hasil umbi bawang merah sedang diuji dan diteliti sebagai obat tradisional (antimicrobial, anticancer dan anti-inflammatory) (Shinkafi dan Dauda, 2013). Selain berfungsi sebagai bumbu dapur dan penyedap masakan, bawang merah juga bermanfaat bagi kesehatan diantaranya untuk penyembuhan sembelit, mengontrol tekanan darah, 
menurunkan kolesterol, menurunkan resiko diabetes, mencegah pertumbuhan sel kanker dan mengurangi resiko gangguan hati (Wibowo. 2009).

Pada beberapa tahun belakangan ini, permintaan kebutuhan akan bawang merah terus meningkat dan berdasarkan data Kementrian Pertanian (Kementan) (2017) produktivitas bawang merah pada tahun 2016 turun sebesar 3.93\%. Kendala peningkatan produksi bawang merah menjadikan indonesia masih mengimpor bawang dari luar untuk sebagai umbi konsumsi ataupun benih dan yang menjadi faktor utama hal tersebut disebabkan oleh kurang tersedianya bahan tanam yang bermutu tinggi dan bebas penyakit (Maulidina, 2019).

Bibit bawang merah mengalami kesulitan untuk dikembangkan karena keterbatasan ketersediaan varietas lokal. Hingga menjadikan petani memilih mengembangkan varietas dari asal impor, seperti varietas impor Ilokos dan Tanduyung yang karakteristik pertumbuhannya berbeda dari segi ukuran yang lebih besar, kandungan air yang lebih banyak serta warnanya yang lebih terlihat pucat, sementara untuk aroma yang dihasilkan jauh lebih rendah jika dibandingkan dengan bawang merah varietas lokal. Namun kelebihan dari bawang merah varietas ini bisa lebih tahan terhadap serangan hama dan penyakit sehingga lebih banyak dikembangkan dan ditanam petani (Basuki, 2005).

Bawang merah salah satu komoditi dari tanaman hortikultura yang mempunyai nilai jual tinggi dipasaran. Sentra produksi dan budidaya untuk tanaman bawang merah perlu ditingkatkan dengan seiring dari meningkatnya permintaan konsumen dan jumlah penduduk yang kian meningkat seiring waktu. Kebutuhan bawang merah yang terus meningkat memberikan suatu prospek usaha yang cerah untuk di kembangkan (Estu et al., 2007). Upaya untuk meningkatkan produksi bawang merah bisa dilakuakan dengan pemupukan. Karena pemupukan merupakan salah satu faktor pendukung dalam upaya peningkatan hasil tanaman. Dengan pengaplikasian penggunaan pupuk yang sesuai anjuran bisa mejadikan hasil akhir yang menguntungkan tetapi pengaplikasian pupuk yang digunakan diharapkan tidak hanya meningkatkan hasil per satuan luas dengan pemupukan yang efisien karena penggunaan pupuk di tingkat petani untuk meningkatkan hasil tanaman dipergunakan telalu berlebihan jika terus menerus dibiarkan bisa menimbulkan masalah terutama defisiensi unsur hara mikro, pemadatan tanah, dan pencemaran lingkungan (Bangun et al. 2000).

Pemupukan merupakan salah satu upaya yang digunakan untuk meningkatkan pertumbuhan dan hasil tanaman bawang merah. Salah satunya adalah pupuk NPK majemuk yang sekaligus mengandung tiga unsur hara utama yang dibutuhkan tanaman, yaitu N, P, dan K. Pemberian pupuk NPK majemuk diharapkan dapat memberikan hasil pertumbuhan tanaman bawang merah yang maksimal. Sejalan dengan pernyataan Novizan (2010), bahwa unsur hara bagi tanaman harus tercukupi agar pertumbuhan tanaman serta hasil akhir produksinya dapat maksimal. Penambahan unsur hara juga dapat memperbaiki sifat fisika dan kimia tanah yang bisa menunjang pertumbuhan tanaman.

Berdasarkan hal-hal di atas, maka untuk mendapatkan hasil produksi tanaman bawang merah yang tinggi dengan jenis 2 varietas bawang merah yang berbeda, perlu dicari dosis larutan pupuk yang tepat dengan lebih memperhatikan kebutuhan tanaman dan kondisi agroekosistemnya. Dimana hasil akhir tujuan dari penelitian ini adalah untuk mendapatkan dosis larutam pupuk NPK majemuk yang optimal untuk 2 varietas bawang merah yang berintroduksi pada lingkungan agroekosistem lahan dataran tinggi. 


\section{METODE PENELITIAN}

Penelitian ini dilakukan di screen house yang berada di Balai Penelitian Tanaman Sayuran (BALITSA) Lembang, pada bulan September sampai Desember 2020. Adapun alat yang digunakan dalam penelitian adalah cangkul, timbangan, dan termohigrometer, gentong, ember, gayung, penggaris/meteran, kamera, alat tulis, label, gunting, gelas ukur, suntikan, colour chart, polynet dan sprayer. Bahan digunakan diantaranya yaitu benih bawang merah (varietas Sembrani dan Mentes), air, pupuk NPK Mutiara (16:16:16), pupuk kandang, dolomit, herbisida, dan pestisida.

Metode Penelitian yang digunakan adalah metode eksperimental dengan rancangan percobaan yang digunakan adalah Rancangan Acak Kelompok (RAK) faktor tunggal yang terdiri dari 6 perlakuan yaitu A (Varietas Sembrani dan $100 \mathrm{ml} /$ polybag), B (Varietas Sembrani dan $120 \mathrm{ml} /$ polybag), C (Varietas Sembrani dan $140 \mathrm{ml} /$ polybag), D (Varietas Mentes dan $100 \mathrm{ml} /$ polybag), E (Varietas Mentes dan $120 \mathrm{ml} / \mathrm{polybag}$ ), dan F (Varietas Mentes dan $140 \mathrm{ml} /$ polybag) di ulang sebanyak 4 kali sehingga total terdapat 24 unit percobaan.

Variabel pengamatan yaitu Tinggi Tanaman, Jumlah Anakan, Jumlah Daun,
Jumlah Umbi, Diameter Umbi, Panjang Umbi, Berat Umbi Segar dengan Daun/Rumpun, Berat Umbi Segar dengan Daun/Plot, Berat Umbi Kering dengan Daun/Rumpun, Berat Umbi Kering dengan Daun/Plot, Warna Daun dan Warna Umbi. Data dianalisis dengan dianalisis dengan menggunakan uji $\mathrm{F}$ pada taraf $5 \%$ pada semua variabel yang diamati. Jika data yang dihasilkan antar perlakuan berbeda nyata, untuk mengetahui pertumbuhan dan hasil tertinggi maka dilakukan uji lanjut dengan uji jarak berganda (DMRT) taraf 5\%.

\section{HASIL DAN PEMBAHASAN}

Pengamatan pertumbuhan vegetatifgeneratif tanaman bawang merah diamati pada saat tanaman berumur 60-70 HST. Hasil analisis sidik ragam dan hasil uji Duncan Multiple Range Test (DMRT) taraf 5\% menunjukkan bahwa jenis varietas tanaman bawang merah dan pemberian dosis larutan pupuk NPK mutiara (16:16:16) yang berbeda memberikan pengaruh nyata terhadap semua parameter pengamatan. Salah satunya pada tinggi tanaman bawang merah. Hasil hasil uji Duncan Multiple Range Test (DMRT) taraf 5\% disajikan pada Tabel 1.

Tabel 1. Rata-rata Tinggi Tanaman Bawang Merah (Allium ascalonicum L.)

\begin{tabular}{clc}
\hline Kode & Perlakuan & Tinggi Tanaman $(\mathrm{cm})$ \\
\hline $\mathrm{A}$ & Varietas Sembrani dan 100 ml/polybag & $33,07 \mathrm{~b}$ \\
$\mathrm{~B}$ & Varietas Sembrani dan 120 ml/polybag & $34,26 \mathrm{~b}$ \\
$\mathrm{C}$ & Varietas Sembrani dan 140 ml/polybag & $33,61 \mathrm{~b}$ \\
$\mathrm{D}$ & Varietas Mentes dan 100 ml/polybag & $41,80 \mathrm{a}$ \\
$\mathrm{E}$ & Varietas Mentes dan 120 ml/polybag & $44,49 \mathrm{a}$ \\
$\mathrm{F}$ & Varietas Mentes dan 140 ml/polybag & $43,74 \mathrm{a}$ \\
\hline \multicolumn{6}{c}{ KK } & 12,53\% \\
\hline Keterangan: Nilai rata-rata yang diikuti huruf yang sama pada setiap kolom yang \\
& sama menunjukkan tidak berbeda nyata pada uji jarak berganda
\end{tabular}

Berdasarkan hasil uji lanjut DMRT taraf $5 \%$ rata-rata tinggi tanaman bawang merah tertinggi terdapat pada perlakuan E (Varietas Mentes dan $120 \mathrm{ml} /$ polybag) 
dengan nilai rata-rata yang dihasilkan sebesar 44,49 $\mathrm{cm}$. Berbeda nyata dengan perlakuan A (Varietas Sembrani dan 100 $\mathrm{ml} /$ polybag) yang memberikan hasil terendah dengan nilai rata-rata $33,07 \mathrm{~cm}$, namun tidak berbeda nyata dengan perlakuan lainnya yang menghasilkan nilai rata-rata tinggi tanaman yang hampir serentak.

Perlakuan E (Varietas Mentes dan $120 \mathrm{ml} /$ polybag) menghasilakan rata-rata tertinggi pada pengamatan tinggi tanaman bawang merah. Dapat diketahui bahwa karakter pertumbuhan tanaman bawang merah khususnya pada fase pertumbuhan vegetatif dapat dibedakan berdasarkan genetik bawaan dari tanaman. Hal tersebut sesuai dengan penelitian Putrasamedja
(2010) beberapa jenis tampilan klon bawang merah mampu menunjukkan perbedaan hasil pertumbuhan yang lebih baik jika dibandingkan pada setiap klon satu dengan klon lainya. Oleh sebab itu adanya perbedaan tinggi tanaman disebabkan oleh sifat genetik yang berbeda, sehingga berpengaruh langsung terhadap tinggi tanaman.

Jumlah anakan menunjukkan bahwa jenis varietas tanaman bawang merah dan pemberian dosis larutan pupuk NPK mutiara (16:16:16) yang berbeda memberikan pengaruh nyata terhadap jumlah anakan tanaman bawang merah. Hasil uji Duncan Multiple Range Test (DMRT) taraf 5\% disajikan pada Tabel 2.

Tabel 2. Rata-rata Jumlah Anakan Tanaman Bawang Merah (Allium ascalonicum L.)

\begin{tabular}{ccc}
\hline Kode & Perlakuan & Jumlah Anakan \\
\hline A & Varietas Sembrani dan $100 \mathrm{ml} /$ polybag & $2,00 \mathrm{~b}$ \\
B & Varietas Sembrani dan $120 \mathrm{ml} /$ polybag & $1,97 \mathrm{~b}$ \\
C & Varietas Sembrani dan $140 \mathrm{ml} /$ polybag & $2,22 \mathrm{~b}$ \\
D & Varietas Mentes dan $100 \mathrm{ml} /$ polybag & $3,14 \mathrm{a}$ \\
E & Varietas Mentes dan $120 \mathrm{ml} /$ polybag & $2,85 \mathrm{a}$ \\
F & Varietas Mentes dan $140 \mathrm{ml} /$ polybag & $3,00 \mathrm{a}$ \\
\hline & KK & $10,97 \%$ \\
\hline
\end{tabular}

Keterangan: Nilai rata-rata yang diikuti huruf yang sama pada setiap kolom yang sama menunjukkan tidak berbeda nyata pada uji jarak berganda DMRT pada taraf $5 \%$.

Berdasarkan hasil uji lanjut DMRT taraf 5\% rata-rata jumlah anakan tanaman bawang merah tertinggi terdapat pada perlakuan D (Varietas Mentes dan 100 $\mathrm{ml} /$ polybag) dengan nilai rata-rata yang dihasilkan sebesar 3,14. Berbeda nyata dengan perlakuan B (Varietas Sembrani dan $120 \mathrm{ml} /$ polybag) yang memberikan hasil terendah dengan nilai rata-rata 1,97 , namun tidak berbeda nyata dengan perlakuan lainnya yang menghasilkan nilai rata-rata jumlah anakan yang hampir serentak.

Perlakuan D (Varietas Mentes dan $100 \mathrm{ml} /$ polybag) menghasilkan jumlah anakan tertinggi dengan nilai rata-rata yang dihasilkan sebesar 3,14. Faktor genetik dari varietas bawang merah menunjukan bahwa varietas Mentes menghasilkan jumlah anakan yang lebih banyak di bandingkan dengan varietas Sembrani karena karakter umbi varietas Sembrani relatif menghasilkan umbi yang besar sehingga jumlah anakannya lebih sedikit, berbanding terbalik dengan bawang merah varietas Mentes yang jenis umbinya kecil sehingga jumlah anakan yang dihasilkan lebih banyak. Hal ini sejalan dengan pernyataan Yamaguci (1983) dalam Putrasamedja (2010), bahwa faktor utama 
dari adanya keberagaman disebabkan oleh perbedaan keturunan. Salah satunya hasil dari jumlah anakan setiap 2 varietas bawang merah bisa berbeda-beda dan apabila jumlah anakan yang dimiliki sedikit maka umbi akan besar, sehingga berpengaruh terhadap berat umbi ataupun perkembangan hasil tanaman bawang merah lainnya.
Jumlah daun menunjukkan bahwa jenis varietas tanaman bawang merah dan pemberian dosis larutan pupuk NPK mutiara (16:16:16) yang berbeda memberikan pengaruh nyata terhadap jumlah daun tanaman bawang merah. Hasil uji Duncan Multiple Range Test (DMRT) taraf 5\% disajikan pada Tabel 3.

Tabel 3. Rata-rata Jumlah Daun Tanaman Bawang Merah (Allium ascalonicum L.)

\begin{tabular}{ccc}
\hline Kode & Perlakuan & Jumlah Daun \\
\hline A & Varietas Sembrani dan 100 ml/polybag & $3,71 \mathrm{~b}$ \\
B & Varietas Sembrani dan 120 ml/polybag & $3,92 \mathrm{~b}$ \\
$\mathrm{C}$ & Varietas Sembrani dan 140 ml/polybag & $4,68 \mathrm{~b}$ \\
$\mathrm{D}$ & Varietas Mentes dan 100 ml/polybag & $6,97 \mathrm{a}$ \\
$\mathrm{E}$ & Varietas Mentes dan 120 ml/polybag & $6,41 \mathrm{a}$ \\
$\mathrm{F}$ & Varietas Mentes dan 140 ml/polybag & $6,73 \mathrm{a}$ \\
\hline & $\mathrm{KK}$ & $11,38 \%$ \\
\hline
\end{tabular}

Keterangan: Nilai rata-rata yang diikuti huruf yang sama pada setiap kolom yang sama menunjukkan tidak berbeda nyata pada uji jarak berganda DMRT pada taraf $5 \%$

Berdasarkan hasil uji lanjut DMRT taraf $5 \%$ rata-rata jumlah daun tanaman bawang merah tertinggi terdapat pada perlakuan D (Varietas Mentes dan 100 $\mathrm{ml} /$ polybag) dengan nilai rata-rata yang dihasilkan sebesar 6,97. Berbeda nyata dengan perlakuan A (Varietas Sembrani dan $100 \mathrm{ml} /$ polybag) yang memberikan hasil terendah dengan nilai rata-rata 3,71 , namun tidak berbeda nyata dengan perlakuan lainnya.

Unsur $\mathrm{N}$ dibutuhkan paling banyak bagi pertumubuhan tanaman bawang merah dan salah satunya untuk perkembangan dan pertumbuhan daun. Nitrogen bisa berfungsi untuk membantu pertumbuhan daun sehingga daun tanaman menjadi lebar dan lebih hijau (Sutedjo, 2010). Selain itu fungsi Kalium juga sebagai unsur hara esensial yang dibutuhkan tanaman bawang merah dalam jumlah yang banyak. Karena Unsur K berperan dalam fotosintesis dan terlibat di dalam sintesis ATP, produksi enzim-enzim fotosintesis seperti RuBP karboksilase, serta berperan dalam penyerapan $\mathrm{CO}_{2}$ melalui mulut daun (Munawar, 2011).

Jumlah umbi menunjukkan bahwa jenis varietas tanaman bawang merah dan pemberian dosis larutan pupuk NPK mutiara (16:16:16) yang berbeda memberikan pengaruh nyata terhadap jumlah umbi tanaman bawang merah. Hasil uji Duncan Multiple Range Test (DMRT) taraf 5\% disajikan pada Tabel 4. 
Tabel 4. Rata-rata Jumlah Umbi Tanaman Bawang Merah (Allium ascalonicum L.)

\begin{tabular}{ccc}
\hline Kode & Perlakuan & Jumlah Umbi \\
\hline A & Varietas Sembrani dan $100 \mathrm{ml} /$ polybag & $2,00 \mathrm{~b}$ \\
B & Varietas Sembrani dan $120 \mathrm{ml} /$ polybag & $2,02 \mathrm{~b}$ \\
C & Varietas Sembrani dan $140 \mathrm{ml} /$ polybag & $2,23 \mathrm{~b}$ \\
D & Varietas Mentes dan $100 \mathrm{ml} /$ polybag & $3,14 \mathrm{a}$ \\
E & Varietas Mentes dan $120 \mathrm{ml} /$ polybag & $2,85 \mathrm{a}$ \\
F & Varietas Mentes dan $140 \mathrm{ml} /$ polybag & $3,00 \mathrm{a}$ \\
\hline & KK & $10,09 \%$ \\
\hline
\end{tabular}

Keterangan: Nilai rata-rata yang diikuti huruf yang sama pada setiap kolom yang sama menunjukkan tidak berbeda nyata pada uji jarak berganda DMRT pada taraf $5 \%$.

Berdasarkan hasil uji lanjut DMRT taraf $5 \%$ rata-rata jumlah umbi tanaman bawang merah tertinggi terdapat pada perlakuan D (Varietas Mentes dan 100 $\mathrm{ml} /$ polybag) dengan nilai rata-rata yang dihasilkan sebesar 3,14. Berbeda nyata dengan perlakuan A (Varietas Sembrani dan $100 \mathrm{ml} /$ polybag) yang memberikan hasil terendah dengan nilai rata-rata 2,00 , namun tidak berbeda nyata dengan perlakuan lainnya.

Rata-rata jumlah umbi tanaman bawang merah tertinggi terdapat pada perlakuan D (Varietas Mentes dan 100 $\mathrm{ml} /$ polybag) dengan nilai rata-rata yang dihasilkan sebesar 3,14. Perbedaan hasil antara bawang merah varietas Mentes dan varietas Sembrani disebabkan olek karakteristik genetik bawaan jenis umbi dengan lingkungan yang sesuai. Hal tersebut sejalan menurut Ambarwati dan Yudono (2003), dimana hasil interaksi dari beberapa varietas dan lingkungan yang sesuai menjadikan hasil dari perbedaan genotip untuk hasil umbi menjadi berbeda nyata pada setiap lingkungan. Hasil jumlah anakan dari tanaman bawang merah yang sedikit menjadikan hasil umbi bawang merah yang berukuran besar sehingga hasil akhirnya produksi dari umbi tanaman bawang merah prodiktivitasnya tinggi (Silalahi, 2007).

Diameter umbi menunjukkan bahwa jenis varietas tanaman bawang merah dan pemberian dosis larutan pupuk NPK mutiara (16:16:16) yang berbeda memberikan pengaruh nyata terhadap diameter umbi tanaman bawang merah. Hasil uji Duncan Multiple Range Test (DMRT) taraf 5\% disajikan pada Tabel 5.

Tabel 5. Rata-rata Diameter Umbi Tanaman Bawang Merah (Allium ascalonicum L.)

\begin{tabular}{ccc}
\hline Kode & Perlakuan & Diameter Umbi $(\mathrm{mm})$ \\
\hline A & Varietas Sembrani dan 100 ml/polybag & $21,18 \mathrm{ab}$ \\
B & Varietas Sembrani dan 120 ml/polybag & $20,66 \mathrm{ab}$ \\
$\mathrm{C}$ & Varietas Sembrani dan $140 \mathrm{ml} /$ polybag & $22,58 \mathrm{a}$ \\
$\mathrm{D}$ & Varietas Mentes dan $100 \mathrm{ml} /$ polybag & $16,78 \mathrm{c}$ \\
$\mathrm{E}$ & Varietas Mentes dan $120 \mathrm{ml} /$ polybag & $18,19 \mathrm{bc}$ \\
$\mathrm{F}$ & Varietas Mentes dan $140 \mathrm{ml} /$ polybag & $16,20 \mathrm{c}$ \\
\hline & KK & $10,05 \%$ \\
\hline
\end{tabular}

Keterangan: Nilai rata-rata yang diikuti huruf yang sama pada setiap kolom yang sama menunjukkan tidak berbeda nyata pada uji jarak berganda DMRT pada taraf 5\% 
Berdasarkan hasil uji lanjut DMRT taraf 5\% rata-rata diameter umbi tanaman bawang merah tertinggi terdapat pada perlakuan C (Varietas Sembrani dan 140 $\mathrm{ml} /$ polybag) dengan nilai rata-rata yang dihasilkan sebesar $22,58 \mathrm{~mm}$, dan tidak berbeda nyata dengan perlakuan A dan B yang memiliki nilai selisih yang tidak berbeda jauh. Namun berbeda nyata dengan perlakuan F (Varietas Mentes dan 140 $\mathrm{ml} /$ polybag) yang memberikan hasil terendah dengan nilai rata-rata $16,20 \mathrm{~mm}$, sedangkan untuk nilai rata-rata diameter umbi perlakuan $\mathrm{E}$ dan $\mathrm{F}$ memiliki nilai selisih yang tidak berbeda jauh.

Pencahayaan yang cukup maksimal pada sekitar lingkungan perlakuan $\mathrm{C}$ (Varietas Sembrani dan $140 \mathrm{ml} /$ polybag) dengan nilai rata-rata yang dihasilkan sebesar 22,58 $\mathrm{mm}$, menyebabkan diameter umbi pada perlakuan $\mathrm{C}$ memberikan hasil tertinggi dengan ukurannya yang lebih besar dibandingkan dengan bawang merah varietas Mentes. Hal tersebut sejalan dengan penyataan Roesmarkram et al. (2002), bahwa hasil dari cahaya untuk yang dihasilkan untuk proses fotosintesis yang baik akan menghasilkan bentuk umbi yang besar. Selain itu hasil dari penelitian Istiani 2016 menunjukan bahwa hasil panen dari tanaman bawang merah menghasilkan panjang dan diameter umbi bawang merah \ yang lebih berisi padat, dengan warnanya yang lebih merah, dan hasil dari ukuran umbi yang seimbang antara panjang dan diameter umbi. penggunaan unsur pupuk mikro dengan komposisi kandungan yang sesuai antara $\mathrm{N}, \mathrm{P}$ dan $\mathrm{K}$ yang seimbang menjadikan tanaman dapat memanfaatkan kandungan dari pupuk tersebut dan memprosesnya dengan sesuai.

Panjang umbi menunjukkan bahwa jenis varietas tanaman bawang merah dan pemberian dosis larutan pupuk NPK mutiara (16:16:16) yang berbeda memberikan pengaruh nyata terhadap panjang umbi tanaman bawang merah. Hasil uji Duncan Multiple Range Test (DMRT) taraf 5\% disajikan pada Tabel 6.

Tabel 6. Rata-rata Panjang Umbi Tanaman Bawang Merah (Allium ascalonicum L.)

\begin{tabular}{clc}
\hline Kode & Perlakuan & Panjang Umbi (mm) \\
\hline $\mathrm{A}$ & Varietas Sembrani dan 100 ml/polybag & $31,48 \mathrm{a}$ \\
$\mathrm{B}$ & Varietas Sembrani dan 120 ml/polybag & $30,17 \mathrm{a}$ \\
$\mathrm{C}$ & Varietas Sembrani dan 140 ml/polybag & $30,20 \mathrm{a}$ \\
$\mathrm{D}$ & Varietas Mentes dan 100 ml/polybag & $21,49 \mathrm{~b}$ \\
$\mathrm{E}$ & Varietas Mentes dan 120 ml/polybag & $22,93 \mathrm{~b}$ \\
$\mathrm{~F}$ & Varietas Mentes dan 140 ml/polybag & $21,45 \mathrm{~b}$ \\
\hline \multicolumn{2}{c}{ KK } & $6,94 \%$ \\
\hline Keterangan: Nilai rata-rata yang diikuti huruf yang sama pada setiap kolom yang \\
& sama menunjukkan tidak berbeda nyata pada uji jarak berganda
\end{tabular}

Berdasarkan hasil uji lanjut DMRT taraf 5\% rata-rata panjang umbi tanaman bawang merah tertinggi terdapat pada perlakuan A (Varietas Sembrani dan 100 $\mathrm{ml} /$ polybag) dengan nilai rata-rata yang dihasilkan sebesar 31,48 mm. Berbeda nyata dengan perlakuan F (Varietas Mentes dan $140 \mathrm{ml} /$ polybag) yang memberikan hasil terendah dengan nilai rata-rata $21,45 \mathrm{~mm}$, namun tidak berbeda nyata dengan perlakuan lainnya yang menghasilkan nilai rata-rata panjang umbi yang hampir serentak.

Bawang merah varietas Sembrani dilihat dari jenis umbi relatif lebih berukuran besar dan panjang terlihat pada hasil 
pengamatan pada perlakuan A (Varietas Sembrani dan $100 \mathrm{ml} /$ polybag) dengan nilai rata-rata sebesar $31,48 \mathrm{~mm}$, menghasilkan nilai tertinggi panjang umbi dan hasil panjang umbi varietas Sembrani yang hasilnya berbeda nyata dengan bawang merah varietas Mentes yang umbinya berukuran sedang-kecil. Selain hal tersebut di duga karena pengolahan tanah yang kurang maksimal sehingga menjadikan tanah kurang gembur, serta lingkungan pada screen house yang kurang cocok menjadi faktor penghambat dalam perkembangan besar umbi di dalam tanah. Sejalan dengan menurut Sutrisna et al. (2003) bahwa unsur hara terutama $\mathrm{K}$ di dalam tanah dibutuhkan sebagai penyeimbang untuk proses sintesis karbohidrat dan protein memebentuk hasil umbi bawang merah yang besar. Sejalan dengan hasil penelitian Istiani (2016), bahwa hasil dari panen menunjukan hasil panjang dan diameter umbi bawang merah ukuran besar dengan umbi yang lebih berisi padat sehingga bisa mempengaruhi produksi yang dihasilkan baik.

Berat umbi segar dengan daun/rumpun menunjukkan bahwa jenis varietas tanaman bawang merah dan pemberian dosis larutan pupuk NPK mutiara (16:16:16) yang berbeda memberikan pengaruh nyata terhadap berat umbi segar dengan daun/rumpun. Hasil uji Duncan Multiple Range Test (DMRT) taraf 5\% disajikan pada Tabel 7.

Tabel 7. Rata-rata Berat Umbi Segar dengan Daun/Rumpun

\begin{tabular}{clc}
\hline \multirow{2}{*}{ Kode } & Perlakuan & $\begin{array}{c}\text { Berat Umbi Segar dengan Daun/Rumpun } \\
(\mathrm{g})\end{array}$ \\
\hline A & Varietas Sembrani dan 100 ml/polybag & $4,63 \mathrm{~b}$ \\
B & Varietas Sembrani dan 120 ml/polybag & $5,11 \mathrm{~b}$ \\
C & Varietas Sembrani dan 140 ml/polybag & $5,10 \mathrm{~b}$ \\
D & Varietas Mentes dan 100 ml/polybag & $6,94 \mathrm{a}$ \\
E & Varietas Mentes dan 120 ml/polybag & $7,11 \mathrm{a}$ \\
F & Varietas Mentes dan 140 ml/polybag & $6,84 \mathrm{a}$ \\
\hline & KK & $15,83 \%$ \\
\hline
\end{tabular}

Keterangan: Nilai rata-rata yang diikuti huruf yang sama pada setiap kolom yang sama menunjukkan tidak berbeda nyata pada uji jarak berganda DMRT pada taraf $5 \%$

Berdasarkan hasil uji lanjut DMRT taraf $5 \%$ rata-rata berat umbi segar dengan daun/rumpun tertinggi terdapat pada perlakuan E (Varietas Mentes dan 120 $\mathrm{ml} /$ polybag) dengan nilai rata-rata yang dihasilkan sebesar 7,11 g. Berbeda nyata dengan perlakuan A (Varietas Sembrani dan $100 \mathrm{ml} /$ polybag) yang memberikan hasil terendah dengan nilai rata-rata $4,63 \mathrm{~g}$, namun tidak berbeda nyata dengan perlakuan lainnya.

Ukuran yang dihasilkan umbi dari masing-masing varietas (Sembrani dan Mentes) berbeda menyebabkan bobot basah dan kering berbeda nyata antar perlakuan dan selain itu hasil umbi varietas Sembrani kurang maksimal dibandingkan hasil umbi varietas Mentes. Hasil perlakuan A (Varietas Sembrani dan $100 \mathrm{ml} /$ polybag) yang memberikan hasil terendah dengan nilai rata-rata 4,63 g, diduga kurang cocoknya varietas tersebut beradaptasi dengan lingkungan. Karena faktor lingkungan merupakan unsur yang sangat penting dalam proses budidaya tanaman sehingga lingkungan yang kurang cocok bisa berpengaruh terhadap proses pertumbuhan dan sistem kerja mikroba tanah dalam untuk mengfiksasi dan melarutkan unsur nitrogen dan fosfat. Sejalan dengan penyataan Sutedjo (2010), bahwa yang mempengaruhi proses dalam transformasi nitrogen 
diantaranya tanah, suhu,kelembaban, pupuk, dan kapur aktif serta lingkungan yang sesuai.

Berat umbi segar dengan daun/plot menunjukkan bahwa jenis varietas tanaman bawang merah dan pemberian dosis larutan pupuk NPK mutiara (16:16:16) yang berbeda memberikan pengaruh nyata terhadap berat umbi segar dengan daun/plot. Hasil uji Duncan Multiple Range Test (DMRT) taraf 5\% disajikan pada Tabel 8.

Tabel 8. Rata-rata Berat Umbi Segar dengan Daun/Plot

\begin{tabular}{clc}
\hline \multirow{2}{*}{ Kode } & Perlakuan & $\begin{array}{c}\text { Berat Umbi Segar dengan Daun/Plot } \\
(\mathrm{g})\end{array}$ \\
\hline A & Varietas Sembrani dan 100 ml/polybag & $11,95 \mathrm{c}$ \\
B & Varietas Sembrani dan 120 ml/polybag & $13,54 \mathrm{c}$ \\
C & Varietas Sembrani dan $140 \mathrm{ml} /$ polybag & $11,69 \mathrm{bc}$ \\
D & Varietas Mentes dan 100 ml/polybag & $18,47 \mathrm{ab}$ \\
E & Varietas Mentes dan 120 ml/polybag & $19,93 \mathrm{a}$ \\
F & Varietas Mentes dan 140 ml/polybag & $19,74 \mathrm{a}$ \\
\hline & KK & $21,55 \%$ \\
\hline
\end{tabular}

Keterangan: Nilai rata-rata yang diikuti huruf yang sama pada setiap kolom yang sama menunjukkan tidak berbeda nyata pada uji jarak berganda DMRT pada taraf 5\%

Berdasarkan hasil uji lanjut DMRT taraf 5\% rata-rata berat umbi segar dengan daun/plot tertinggi terdapat pada perlakuan E (Varietas Mentes dan $120 \mathrm{ml} /$ polybag) dengan nilai rata-rata yang dihasilkan sebesar 19,93 g, tidak berbeda nyata dengan perlakuan $\mathrm{D}$ dan $\mathrm{F}$ yang memiliki nilai selisih hasil rata-rata berat umbi segar dengan daun/plot yang tidak berbeda jauh. Namun berbeda nyata dengan perlakuan A (Varietas Sembrani dan $100 \mathrm{ml} /$ polybag) yang memberikan hasil terendah dengan nilai rata-rata $11,95 \mathrm{~g}$, sedangkan untuk ratarata hasil berat umbi segar dengan daun/plot perlakuan $\mathrm{A}$ dan $\mathrm{C}$ memiliki nilai selisih yang tidak berbeda jauh.

Berat umbi segar dengan daun/plot tertinggi terdapat pada perlakuan E (Varietas Mentes dan $120 \mathrm{ml} /$ polybag), diakibatkan oleh beberapa pengaruh pemberian pupuk NPK, dimana unsur yang terkandung dalam pupuk tersebut dapat memberi pengaruh dalam pembentukan umbi terutama unsur $\mathrm{K}$ yang bisa berperan untuk pembentukan umbi serta meningkatkan aktifitas fotosintesis dan kandungan klorofil daun sehingga dapat meningkatkan berat basah ataupun kering hasil umbi bawang merah. Hal ini sesuai dengan pernyataan Napitupulu dan Winarto (2010) bahwa unsur yang terkadung dalam kalium bisa meningkatkan hasil pertumbuhan pada fase vegetatif tanaman diantaranya mempengaruhi pembentukan, pembesaran, ataupun pemanjangan umbi hingga memperngaruhi hasil bobot bawang merah. Sesuai dengan penyataan Damanik et al. (2010), bahwa dalam proses pembentukan umbi harus mengalami proses fotosintesis cukup baik maka dari itu selalin faktor cahaya yang cukup, hal lain yang diperlukan ialah unsur kalium yang cukup untuk meningkatkan berat umbi.

Berat Umbi Kering dengan Daun/Rumpun menunjukkan bahwa jenis varietas tanaman bawang merah dan pemberian dosis larutan pupuk NPK mutiara (16:16:16) yang berbeda memberikan pengaruh nyata terhadap berat umbi kering dengan daun/rumpun. Hasil uji Duncan Multiple Range Test (DMRT) taraf 5\% disajikan pada Tabel 9. 
Tabel 9. Rata-rata Berat Umbi Kering dengan Daun/Rumpun

\begin{tabular}{clc}
\hline \multirow{2}{*}{ Kode } & Perlakuan & $\begin{array}{c}\text { Berat Umbi Kering dengan Daun/Rumpun } \\
(\mathrm{g})\end{array}$ \\
\hline A & Varietas Sembrani dan 100 ml/polybag & $3,88 \mathrm{~b}$ \\
B & Varietas Sembrani dan 120 ml/polybag & $4,55 \mathrm{~b}$ \\
C & Varietas Sembrani dan 140 ml/polybag & $4,24 \mathrm{~b}$ \\
D & Varietas Mentes dan 100 ml/polybag & $5,82 \mathrm{a}$ \\
E & Varietas Mentes dan 120 ml/polybag & $5,90 \mathrm{a}$ \\
F & Varietas Mentes dan 140 ml/polybag & $5,78 \mathrm{a}$ \\
\hline
\end{tabular}

\begin{tabular}{ccclll}
\hline \multicolumn{1}{c}{ KK } & \multicolumn{1}{c}{$14,19 \%$} \\
\hline Keterangan: & Nilai rata-rata yang diikuti huruf yang sama pada setiap kolom yang \\
sama menunjukkan & tidak berbeda nyata pada uji jarak berganda \\
DMRT pada taraf 5\%
\end{tabular}

Berdasarkan hasil uji lanjut DMRT taraf 5\% rata-rata berat umbi kering dengan daun/rumpun tertinggi terdapat pada perlakuan E (Varietas Mentes dan 120 $\mathrm{ml} /$ polybag) dengan nilai rata-rata yang dihasilkan sebesar 5,90 g. Berbeda nyata dengan perlakuan A (Varietas Sembrani dan $100 \mathrm{ml} /$ polybag) yang memberikan hasil terendah dengan nilai rata-rata $3,88 \mathrm{~g}$, namun tidak berbeda nyata dengan perlakuan lainnya.

Hasil pertimbuhan dan produksi akhir yang baik terjadi apabila kedua faktor saling berpengaruh baik maka dapat dilihat pada hasil berat umbi kering dengan daun/rumpun tertinggi terdapat pada perlakuan E (Varietas Mentes dan 120 $\mathrm{ml} /$ polybag) dengan nilai rata-rata yang dihasilkan sebesar $5,90 \mathrm{~g}$. Hal ini sesuai dengan pendapat elfin (2017), yang menyatakan bahwa pertumbuhan tanaman sangat di pengaruhi oleh beberapa faktor dan jika diantara salah satunya tidak mendukung maka hasil pertumbuhan yang dihasilkan krang maksimal dan apabila faktor yang mempengaruhi pertumbuhan berimbang maka hasil pertumbuhan pun akan mencapai maksimal dan menguntungkan. Dan hal lain yang mungkin menjadi faktor penghambat dari luar dari tanaman itu sendiri yang kurang mendukung untuk aktivitas perlakuan yang bisa saling mempengaruhi, sebab setiap perlakuan dari kombinasi beberapa perlakuan tidak selamanya akan memberikan pengaruh yang baik untuk pertumbuhan dan hasil tanaman.

Berat umbi kering dengan daun/plot menunjukkan bahwa jenis varietas tanaman bawang merah dan pemberian dosis larutan pupuk NPK mutiara (16:16:16) yang berbeda memberikan pengaruh nyata terhadap berat umbi kering dengan daun/plot. Hasil uji Duncan Multiple Range Test (DMRT) taraf 5\% disajikan pada Tabel 10. 
Tabel 10. Rata-rata Berat Umbi Kering dengan Daun/Plot

\begin{tabular}{|c|c|c|}
\hline Kode & Perlakuan & $\begin{array}{l}\text { Berat Umbi Kering dengan } \\
\text { Daun/Plot }(\mathrm{g})\end{array}$ \\
\hline A & Varietas Sembrani dan 100 ml/polybag & $10,79 \mathrm{~b}$ \\
\hline $\mathrm{B}$ & Varietas Sembrani dan $120 \mathrm{ml} /$ polybag & $11,53 \mathrm{ab}$ \\
\hline $\mathrm{C}$ & Varietas Sembrani dan $140 \mathrm{ml} /$ polybag & $11,26 \mathrm{~b}$ \\
\hline $\mathrm{D}$ & Varietas Mentes dan $100 \mathrm{ml} /$ polybag & $15,15 \mathrm{ab}$ \\
\hline $\mathrm{E}$ & Varietas Mentes dan $120 \mathrm{ml} /$ polybag & 16,19 a \\
\hline $\mathrm{F}$ & Varietas Mentes dan $140 \mathrm{ml} /$ polybag & $16,35 \mathrm{a}$ \\
\hline \multicolumn{2}{|r|}{ KK } & $22,18 \%$ \\
\hline rangan: & $\begin{array}{lcll}\text { Nilai rata-rata yang } & \text { diikuti } & \text { huruf } \\
\text { sama } & \text { menunjukkan } & \text { tidak } & \text { berbeda } \\
\text { DMRT pada taraf 5\% } & & \end{array}$ & $\begin{array}{l}\text { yang sama pada setiap kolom yang } \\
\text { nyata pada uji jarak berganda }\end{array}$ \\
\hline
\end{tabular}

Berdasarkan hasil uji lanjut DMRT taraf 5\% rata-rata berat umbi segar dengan daun/rumpun tertinggi terdapat pada perlakuan F (Varietas Mentes dan 140 ml/polybag) dengan nilai rata-rata yang dihasilkan sebesar 16,35 g. Berbeda nyata dengan perlakuan A (Varietas Sembrani dan $100 \mathrm{ml} /$ polybag) yang memberikan hasil terendah dengan nilai rata-rata $10,79 \mathrm{~g}$, namun tidak berbeda nyata dengan perlakuan lainnya.

Ukuran umbi bawang merah varietas Sembrani jelas lebih besar di bandingkan dengan jenis varietas Mentes namun produksi hasil akhir umbi varietas Sembrani lebih sedikit dibandingkan dengan varietas Mentes terlihat pada hasil berat umbi segar dengan daun/rumpun tertinggi terdapat pada perlakuan F (Varietas Mentes dan 140 $\mathrm{ml} /$ polybag) dengan nilai rata-rata yang dihasilkan sebesar 16,35 g. Sejalan dengan hasil penelitian Elisa et al., 2013, diketahui bahwa hasil dari pertumbuhan bawang merah dari varietas (Sembrani, Kuning, Medan dan Tuk-Tuk) memiliki potensi yang cukup baik untuk dikembangkan di dataran rendah ataupun tinggi. Tetapi berdasarkan deskripsi dari setiap varietas diketahui bahwa produksi tersebut masih jauh dibawah kisaran deskripsi. Banyak faktor yang menjadi penyebab hal tersebut, antara lain faktor iklim yang tidak mendukung pada saat pertumbuhan tanaman, $\mathrm{pH}$ tanah yang berbeda.

Pengamatan warna daun dan umbi merupakan salah satu karakteristik bawang merah yang diamati dengan kasat mata menggunakan alat berupa Colour Chart. Dari hasil pengamatan diketahui Warna daun di amati dengan menggunakan alat bantu berupa bagan warna daun (BWD) atau disebut juga Colour Chart. Hasil dari pengamatan menunjukan bahwa warna daun dari varietas sembrani termasuk moderate olive green B dan untuk varietas mentes moderate olive green A. Kedua varietas tanaman bawang tersebut masih dalam lingkup warna green group yang tidak bejauh beda. Untuk warna umbi bawang merah varietas sembrani berwarna strong reddish purple dan untuk umbi varietas mentes berwarna strong reddish purple. Kedua varietas tanaman bawang tersebut masih dalam lingkup warna red-purple group yang tidak bejauh beda. Sejalan dengan pendapat dari Borojevic, (1990) bahwa setiap galur mampu membentuk suatu genotipe yang mampu beradaptasi pada lingkungan yang berbed. Dengan demikian, hasil dari pertumbuhan tanaman dapat diketahui baik jika hasilnya dapat maksimal ketika sudah bisa beradaptasi dengan baik pada lingkup lingkungan yang luas. Pada umumnya untuk galur murni atau 
populasi yang homogen secara genetik, stabilitasnya sangat tergantung pada penyangga individu (individual buffering). Dengan demikian stabilitas hasil ditentukan oleh komposisi genetik galur dengan reaksi genotipe secara individu dan populasi secara keseluruhan terhadap lingkungan.

\section{KESIMPULAN}

Terdapat pengaruh nyata jenis varietas bawang merah dan dosis larutan pupuk NPK Mutiara. Jenis varietas bawang merah yang berbeda menunjukan bahwa varietas Mentes memberikan hasil tertinggi tinggi tanaman, jumlah anakan, jumlah daun, jumlah umbi, berat umbi segar dengan daun/rumpun, berat umbi segar dengan daun/plot, berat umbi kering dengan daun/rumpun, berat umbi kering dengan daun/plot. Sedangkan bawang merah varietas Sembrani memberikan hasil tertinggi pada diameter umbi dan panjang umbi tanaman bawang merah (Allium ascalonicum L.).

\section{UCAPAN TERIMA KASIH}

Terimakasih kepada bapak Drs. R. Prasodjo Soedomo, APU., Dr. Ir Wagiono, bapak Nurcahyo Widyodaru Saputro, S.Si., M.Sc. sebagai pembimbing. Serta semua pihak yang telah membantu dalam pelaksanaan penelitian maupun penulisan ini.

\section{DAFTAR PUSTAKA}

Ambarwati, E., dan Yudono, (2003), "Keragaan Stabilitas Hasil Bawang Merah". Jurnal Ilmu Pertanian, 10 (2) : 1-10.

Bangun, E., M. Nur, H.I., F.H. Silalahi, dan J. Ali. 2000. Pengkajian Teknologi Pemupukan Bawang Merah di Sumatera Utara. Prosiding Seminar Nasional Teknologi Spesifik Lokasi Menuju Desentralisasi Pembangunan Pertanian. 338-342 Hlm.
Basuki, S. R., 2005. Daya Hasil dan Preferensi Petani terhadap Varietas Bawang Merah Lokal dari Berbagai Daerah. Laporan Hasil Penenlitian APBN 2005-ROPP DI. 8 Hlm.

Borojevic, S., (1990), Principles and Methods of Plant Breeding, Elselvier Science Publishier By Amsterdam, Netherland.

Damanik, M., B. E. Hasibuan, Fauzi, Sarifuddin, H. Hanum., 2010. Kesuburan Tanah dan Pemupukan.USU Press. Medan.

Elfin, Efendi. 2017. Respon Pemberian Pupuk Npk Mutiara Dan Bokashi Jerami Padi Terhadap Pertumbuhan dan Produksi Tanaman Bawang Merah (Allium ascalonicum L). Fakultas Pertanian Universitas Asahan-Sumatera. Jurnal Penelitian Pertanian 13 (3) :0216-7689.

Elisa Manora Sinaga, dkk. 2013. Adaptasi Beberapa Varietas Bawang Merah (Allium Ascalonicum L.) Di Dataran Rendah Medan. Fakultas Pertanian USU-Medan. Jurnal Agroekoteknologi Vol.1, No.3.

Estu, Rahayu, dan Berlian VA, Nur. 2007. Bawang merah. Penebar Swadaya. Jakarta.

Istiana, Ida N. 2016. Peningkatan Produksi Bawang Merah Melalui Teknik Pemupukan NPK. Balai Pengkajian Teknologi Pertanian Riau. Jurnal Agro Vol. III, No. 1.

[Kementan] Kementrian Pertanian. 2017. Statistik pertanian 2017. http://epublikasi.setjen.pertanian.go.i d [10 Mei 2020]. 
Putrasamedja, S. 2010. Adaptasi Klon Klon Bawang Merah (Allium ascalonicum L.) di Pabedebilan Losari, Cirebon. Jurnal Agritech. 12 (2) : 81-88.

Roesmarkam, A. Dan N. W. Yuwono. 2002. Ilmu Kesuburan Tanah. Kanisius. Yogyakarta.

Shinkafi, S.A., H. Dauda. 2013. Antibacterial activity of Allium cepa L. on some pathogenic bacteria associated with ocular infections. $J$. App. Med. Sci. 1:147-151.

Silalahi, R. 2007. Pengaruh Lama Perendaman Dan Konsentrasi Kolkhisin Terhadap Jumlah Kromosom, Pertumbuhan, Dan Produksi Bawang Merah (Allium Cepa) Varietas Samosir FMIPA Unimed. Skripsi. FMIPA. Unimed. Medan.

Sutedjo, S M. 2010. Pupuk dan Cara Pemupukan. Rineka Cipta: Jakarta.

Sutrisna, N., S. Suwalan, dan Ishaq. 2003. Uji Kelayakan Teknis dan Finansial Penggunaan Pupuk NPK Anorganik pada Tanaman Kentang Dataran Tinggi Jawa Barat. J. Hort. 13(1):6775.

Maulidina, Nabila. 2019. Pertumbuhan dan Pembungaan Bawang Merah (Allium Cepa L. Aggregatum Group) Varietas Sumenep dan Bima Brebes Sebagai Respon Terhadap Pemupukan Znso4 Dan Perlakuan Night Break. Skripsi Fakultas Pertanian IPB. Bogor.

Munawar, A. 2011. Kesuburan Tanah dan Nutrisi Tanaman. IPB press: Bandung.

Napitupulu, D. dan L. Winarto. 2010. Pengaruh Pemberian Pupuk N dan K terhadap Pertumbuhan dan Produksi Bawang Merah. Balai Pengkajian Teknologi Pertanian Sumatera Utara. J. Hort. Vol. 20 No. 1.

Novizan. 2010. Petunjuk Pemupukan yang Efektif Edisi Revisi. Agromedia. Jakarta. 128 Hlm.

Wibowo, S. 2009. Budidaya Bawang. Penebar Swadaya. Jakarta. 